\title{
PEMAHAMAN NASABAH TERHADAP KONTRAK SYARIAH PADA LEMBAGA KEUANGAN MIKRO SYARIAH DI KOTA DAN KABUPATEN BOGOR
}

\section{UNDERSTANDING OF THE CUSTOMER AGAINST THE ISLAMIC CONTRACTS ON ISLAMIC MICROFINANCE INSTITUTIONS IN BOGOR}

\author{
T.R. Thantawi1a; A. Brawijaya² \\ 1aProgram Studi Perbankan Syariah Fakultas Ekonomi Islam Universitas Djuanda, Jl. Tol \\ Ciawi No. 1, Kotak Pos 35 Bogor 16720 \\ 2Program Studi Perbankan Syariah Fakultas Ekonomi Islam Universitas Djuanda, Jl. Tol \\ Ciawi No. 1, Kotak Pos 35 Bogor 16720
}

\begin{abstract}
This research have goal to know the customer's understanding towards Sharia business contracts with the intent to evaluate so ease in carrying out transactions or economic activities of Sharia with Islamic microfinance institutions. The type of research used in analyzing customer understanding Shariah contract on Islamic microfinance institutions is a descriptive quantitative research methods with likert scale and chi square test. In early research, observations seem understanding client business contract against Sharia in the Islamic microfinance institutions is influenced by many factors, which can generally be categorized into: (1) demographic variables (2) varabel the economic-institutional variables, (3) services-institutional variables, (4) the substance of Islamic business contracts, and (5) variable is socio-cultural community. These variables were analyzed with a deepening understanding of theory over substance, and the theory of business contract the Sharia Islamic microfinance institutions, which in this case is a Cooperative Loan Financing and Sharia.
\end{abstract}

Keywords: comprehension, transactions, contracts, customer, LKMS.

\begin{abstract}
ABSTRAK
Penelitian ini bertujuan untuk mengetahui pemahaman nasabah terhadap kontrak bisnis syariah dengan maksud mengevaluasinya sehingga mempermudah dalam menjalankan transaksi atau kegiatan ekonomi syariah dengan Lembaga Keuangan Mikro Syariah. Jenis penelitian yang digunakan dalam menganalisis pemahaman nasabah terhadap kontrak syariah pada Lembaga Keuangan Mikro Syariah menggunakan metode penelitian deskriptif kuantitatif dengan metode analisis skala likert dan uji chi square. Dalam pengamatan awal penelitian, tampak pemahaman nasabah terhadap kontrak bisnis syariah pada Lembaga Keuangan Mikro Syariah dipengaruhi oleh banyak faktor, yang secara umum dapat dikategorikan menjadi: (1) variabel demografi (2) varabel ekonomi-kelembagaan, (3) variabel pelayanan-kelembagaan, (4) variabel substansi kontrak bisnis syariah, dan (5) variabel sosial budaya masyarakat. Variabel-variabel tersebut dianalisis dengan pendalaman atas substansi teori pemahaman, dan teori kontrak bisnis syariah, Lembaga Keuangan Mikro Syariah yang dalam hal ini ialah Koperasi Simpan Pinjam dan Pembiayaan Syariah.
\end{abstract}

Kata kunci: Pemahaman, transaksi, Kontrak Syariah, nasabah, LKMS. 
Thantawi, T. Rifqy. 2017. Pemahaman Nasabah terhadap Kontrak Syariah pada Lembaga Keuangan Mikro Syariah di Kota dan Kabupaten Bogor. Jurnal Syarikah 3 (2): 463479.

\section{PENDAHULUAN}

Perkembangan pengaturan Lembaga Keuangan Mikro Syariah Undang-Undang Nomor 1 Tahun 2013 tentang Lembaga Keuangan Mikro, terasa pengaruhnya setelah Menteri Koperasi dan Usaha Kecil dan Menengah menerbitkan Peraturan Menteri Koperasi dan Usaha Kecil dan Menengah Nomor 16 /Per/M.KUKM/IX/2015 tentang Pelaksanaan Kegiatan Usaha Simpan Pinjam dan Pembiayaan Syariah oleh Koperasi. Pemerintah beralasan bahwa pelaksanaan kegiatan usaha simpan pinjam dan pembiayaan syariah oleh koperasi semakin berkembang, sesuai dengan dinamika dan perubahan tatanan ekonomi dan sosial masyarakat. Dengan peraturan tersebut terdapat usaha menyeragamkan penamaan bentuk usaha mikro syariah yang sudah ada seperti Baitul Maal wa Tamwil, Koperasi Simpan Pinjam Syariah, Koperasi Jasa Keuangan Syariah, dan lainnya, menjadi Koperasi Simpan Pinjam dan Pembiayaan Syariah, atau jika koperasi konvensional hendak membuka unit syariahnya, maka dibentuk unit koperasi yang bernama Unit Simpan Pinjam dan Pembiayaan Syariah. Peraturan tersebut sebagai suatu upaya penertiban hukum mengenai keberadaan lembaga keuangan mikro syariah sebelum tahun 2015.

Dengan demikian, sudah terdapat pembedaan juga antara Lembaga Keuangan Mikro Syariah dengan Bank Pembiayaan Rakyat Syariah atau yang disingkat dengan BPRS. Hal tersebut juga mempertegas Peraturan Bank Indonesia Nomor 11/23/PBI/2009 tentang Bank Pembiayaan Rakyat Syariah yang menyebutkan bahwa yang dimaksud dengan "lembaga keuangan mikro syariah" adalah antara lain koperasi simpan pinjam syariah, dan Baitul Maal wa Tamwil (BMT).
Persoalan berikutnya ialah bagaimana masyarakat memahami bahwa keberadaaan Lembaga Keuangan Mikro Syariah atau yang dapat direpresentasikan dengan Koperasi Simpan Pinjam dan Pembiayaan Syariah (KSPPS), membantu masyarakat dalam meningkatkan kesejahteraannya.

Persoalan yang juga mendasar ialah ketika masyarakat berinteraksi dengan Lembaga Keuangan Mikro Syariah, sejauhmana masyarakat memahami mengenai akad yang ditawarkan oleh Lembaga Keuangan Mikro Syariah tersebut. Hal ini karena pada dasarnya hubungan antara masyarakat dengan Lembaga Keuangan Mikro Syariah adalah hubungan akad atau kontrak berdasarkan prinsip syariah atau kontrak bisnis syariah.

Namun demikian, masyarakat awam yang menjadi nasabah Lembaga Keuangan Mikro Syariah (yang dalam hal ini direpresentasikan dengan KSPPS) tidak dapat ditelusuri melalui pertanyaanpertanyaan yang rumit seperti syarat subyektif dan syarat obyektif suatu perjanjian, sehingga perlu dilakukan pertanyaan yang relatif mudah, dan dengan jawaban atau tanggapan yang diberikannya, maka dilakukan penafsiran oleh peneliti.

Persoalan tersebut di atas, perlu ditelusuri di lapangan. Peneliti tertarik menelusuri hal tersebut dengan menghubungkan dengan Jawa Barat sebagai representasi keberadaan Lembaga Keuangan Mikro Syariah yang banyak, dan provinsi dengan jumlah penduduk yang banyak pula di Indonesia. Kota dan Kabupaten Bogor merupakan Kota dan Kabupaten dengan jumlah penduduk terbanyak di Provinsi Jawa Barat (Badan Pusat Statistik Provinsi Jawa Barat, 2010 dan 2013), serta terbesar jumlah Unit 
Industri Kecil Menengah dan Besar di Jawa Barat dalam periode tahun 2009 sampai dengan 2012 (Badan Pusat Statistik Provinsi Jawa Barat, 2012), yang mana hal tersebut sangat berkaitan dengan peran Lembaga Keuangan Mikro Syariah.

\section{MATERI DAN METODE}

\section{Teori Pemahaman}

Pemahaman yang terbaik tetap merupakan pemahaman yang diperoleh dari hasil belajar. Hasil belajar pemahaman merupakan tipe belajar yang lebih tinggi dibandingkan tipe belajar pengetahuan (Nana Sudjana, 1992: 24) yang menyatakan bahwa pemahaman dapat dibedakan kedalam 3 kategori, yaitu:

1. Tingkat terendah adalah pemahaman terjemahan, mulai dari menerjemahkan dalam arti yang sebenarnya, mengartikan dan menerapkan prinsipprinsip,

2. Tingkat kedua adalah pemahaman penafsiran yaitu menghubungkan bagian-bagian terendah dengan yang diketahui berikutnya atau menghubungkanbeberapa bagian grafik dengan kejadian, membedakan yang pokok dengan yang tidak pokok dan

3. Tingkat ketiga merupakan tingkat pemaknaan ektrapolasi.

Suke Silversius (1991: 43-44) menyatakan bahwa pemahaman dapat dijabarkan menjadi tiga, yaitu:

1. Menerjemahkan (translation), pengertian menerjemahkan disini bukan saja pengalihan (translation), arti dari bahasa yang satu kedalam bahasa yang lain, dapat juga dari konsepsi abstrak menjadi suatu model, yaitu model simbolik untuk mempermudah orang mempelajarinya. Pengalihan konsep yang dirumuskan dengan kata-kata ke dalam gambar grafik dapat dimasukkan dalam kategori menerjemahkan.

2. Menginterprestasi (interpretation), kemampuan ini lebih luas daripada menerjemahkan yaitu kemampuan untuk mengenal dan memahami ide utama suatu komunikasi.

3. Mengektrapolasi (extrapolation), agak lain dari menerjemahkan dan menafsirkan, tetapi lebih tinggi sifatnya. Ia menuntut kemampuan intelektual yang lebih tinggi.

\section{Teori Persepsi}

Menurut Kamus Besar Bahasa Indonesia, persepsi adalah tanggapan (penerimaan) langsung dari sesuatu, dengan proses seseorang mengetahui beberapa hal melalui panca inderanya (J. S. Badudu, 1994). Persepsi adalah kemampuan otak dalam menerjemahkan stimulus atau proses untuk menerjemahkan stimulus yang masuk ke dalam alat indera manusia. Persepsi manusia terdapat perbedaan sudut pandang dalam penginderaan. Ada yang mempersepsikan sesuatu itu baik atau persepsi yang positif maupun persepsi negatif yang akan mempengaruhi tindakan manusia yang tampak atau nyata (Sugihartono, dkk 2007: 8).

\section{Teori Kontrak Bisnis Syariah.}

Di Indonesia, dengan disahkannya Kompilasi Hukum Ekonomi Islam melalui Peraturan Mahkamah Agung Nomor 2 Tahun 2008, maka terdapat acuan yang lebih kuat mengenai prinsip-prinsip dalam kontrak syariah. Kompilasi Hukum Ekonomi Syariah merupakan upaya "positifisasi" hukum muamalat dalam kehidupan umat Islam di Indonesia yang secara konstitusional sudah dijamin oleh sistem konstitusi Indonesia.

Secara sosiologis, Kompilasi Hukum Ekonomi Syariah disusun sebagai respon terhadap perkembangan baru dalam hukum mu'amalat dalam bentuk praktik ekonomi Syari'ah melalui Lembaga Keuangan Syariah yang memerlukan payung hukum. Secara konstitusional, Kompilasi Hukum Ekonomi Syariah disusun sebagai respon terhadap UndangUndang Nomor 3 Tahun 2006 tentang Perubahan atas Undang-Undang Nomor 7 Tahun 1989 tentang Peradilan Agama, yang 
memperluas kewenangan Peradilan Agama, seperti Hukum Ekonomi Syariah.

Tinjauan Umum Lembaga Keuangan Mikro Syariah

Pada dasarnya Lembaga Keuangan Mikro adalah lembaga keuangan yang khusus didirikan untuk memberikan jasa pengembangan usaha dan pemberdayaan masyarakat, baik melalui pinjaman atau pembiayaan dalam usaha skala mikro kepada anggota dan masyarakat, pengelolaan simpanan, maupun pemberian jasa konsultasi pengembangan usaha yang tidak semata-mata mencari keuntungan (Undang-Undang Nomor 1 Tahun 2013 tentang Lembaga Keuangan Mikro: Pasal 1 angka 1). Seiring dengan perkembangan masyarakat yang memerlukan pengaturan kegiatan usaha berdasarkan prinsip syariah, maka Lembaga Keuangan Mikro dibolehkan melakukan kegiatan usaha berdasarkan prinsip syariah.

Kegiatan usaha Lembaga Keuangan Mikro meliputi jasa pengembangan usaha dan pemberdayaan masyarakat, baik melalui Pinjaman atau Pembiayaan dalam usaha skala mikro kepada anggota dan masyarakat, pengelolaan Simpanan, maupun pemberian jasa konsultasi pengembangan usaha. (Undang-Undang Nomor 1 Tahun 2013 tentang Lembaga Keuangan Mikro: Pasal 11 ayat 1). Penyaluran Pinjaman atau Pembiayaan dan pengelolaan Simpanan oleh LKM sebagaimana dimaksud dalam Pasal 11 ayat (1) dilaksanakan secara konvensional atau berdasarkan prinsip syariah. Kegiatan usaha berdasarkan prinsip syariah sebagaimana dimaksud pada ayat (1) wajib dilaksanakan sesuai dengan fatwa syariah yang dikeluarkan oleh Dewan Syariah Nasional, Majelis Ulama Indonesia. (Undang-Undang Nomor 1 Tahun 2013 tentang Lembaga Keuangan Mikro: Pasal 12 ayat 1 dan 2 ).

\section{Tinjauan Khusus Lembaga Keuangan} Mikro Syariah

Tinjauan khusus Lembaga Keuangan Mikro Syariah dalam hal ini berbentuk badan hukum koperasi yang dalam hal ini ialah Koperasi Syariah (Otoritas Jasa Keuangan, 2016: 2). Umumnya masyarakat mengenal istilah Koperasi Syariah, namun istilah yang baku berdasarkan peraturan perundang-undangan ialah Koperasi Simpan Pinjam dan Pembiayaan Syariah. Pemerintah telah mengaturnya di dalam Peraturan Menteri Koperasi dan Usaha Kecil dan Menengah No. 16/Per/M.KUKM/IX/2015 tentang Pelaksanaan Kegiatan Usaha Simpan Pinjam dan Pembiayaan Syariah oleh Koperasi.

Koperasi Simpan Pinjam dan Pembiayaan Syariah selanjutnya dalam peraturan tersebut di atas disebut KSPPS adalah koperasi yang kegiatan usahanya meliputi simpanan, pinjaman dan pembiayaan sesuai prinsip syariah, termasuk mengelola zakat, infaq/sedekah, dan wakaf (Peraturan Menteri Koperasi dan Usaha Kecil dan Menengah No. 16/Per/M.KUKM/IX/2015 tentang Pelaksanaan Kegiatan Usaha Simpan Pinjam dan Pembiayaan Syariah oleh Koperasi: Pasal 1 angka 1). Selain KSPPS, dikenal pula Unit Simpan Pinjam dan Pembiayaan Syariah Koperasi selanjutnya disebut USPPS Koperasi, yang pengertiannya adalah unit koperasi yang bergerak di bidang usaha meliputi simpanan, pinjaman dan pembiayaan sesuai prinsip syariah, termasuk mengelola zakat, infaq /sedekah, dan wakaf sebagai bagian dari kegiatan koperasi yang bersangkutan.

\section{Jenis Penelitian}

Jenis penelitian yang peneliti gunakan dalam menganalisis pemahaman nasabah terhadap kontrak syariah pada Lembaga Keuangan Mikro Syariah ini merupakan penelitian yang menggunakan metode penelitian deskriptif kuantitatif. Dengan menggunakan metode tersebut, maka diharapkan dapat memberikan gambaran secara umum atas fakta yang terjadi tanpa ada perlakukan atas hal yang akan diteliti.

\section{Populasi dan Sampel}

Populasi pada penelitian ini adalah nasabah Lembaga Keuangan Mikro Syariah 
di Kota dan Kabupaten Bogor. Sedangkan ukuran sampel ditentukan dengan menggunakan metode Slovin (Husein Umar, 2000 : 146). Dengan berdasarkan metode tersebut, maka sampel pada penelitian ini adalah

$$
\mathrm{n}=1+\mathrm{Ne}^{2}
$$

Keterangan:

$$
\begin{array}{ll}
\mathrm{n} & \text { : ukuran sampel } \\
\mathrm{N} & \text { : ukuran Populasi } \\
\mathrm{e} & \text { : error : asumsi 5\% }
\end{array}
$$

(asumsi sampel terdistribusi normal)

Namun demikian, dengan melihat perkembangan di dalam praktik, maka teknik pengambilan sampel menggunakan teknik cluster sampling, teknik pengambilan sampel dimana pemilihan mengacu pada kelompok bukan pada individu. Cara seperti ini baik sekali untuk dilakukan apabila tidak terdapat atau sulit menentukan/menemukan kerangka sampel meski dapat juga dilakukan pada populasi yang kerangka sampel sudah ada.

\section{Objek dan Lokasi Penelitian}

Objek dari penelitian ini adalah Lembaga Keuangan Mikro Syariah dan masyarakat yang menjadi nasabahnya di Kota dan Kabupaten Bogor.

\section{Teknik Pengumpulan Data}

Metode pengumpulan data yang digunakan dalam penelitian ini adalah:

\section{Angket Kuisioner}

Angket kuisioner adalah suatu cara mengumpulkan data dengan memberikan daftar pertanyaan pada responden dengan harapan mereka akan memberikan jawaban atas daftar pertanyaan tersebut. Dengan daftar pertanyaan bersifat tertutup yaitu dengan memberikan alternatifalternatif jawaban yang telah disediakan (Husein Umar, 2000:14).

Kuisioner menggunakan skala likert, skala ini berhubungan dengan pertanyaan tentang sikap seseorang terhadap sesuatu, misalnya setuju-tidak setuju, senang-tidak senang, baik-tidak baik (Husein Umar, 2005: 89).
Dengan menggunakan skala likert 5 poin. Skala ini digunakan dengan cara memberikan daftar pertanyaan pada responden, dengan menjawab berdasar tingkatan jawaban yang tersedia. Mulai dari sangat setuju, setuju, ragu-ragu, tidak setuju, sangat tidak setuju.

2. Wawancara

Wawancara dilakukan dengan mengajukan pertanyaan secara lisan dan menggunakan alat interview guide (panduan wawancara) dalam pertemuan tatap muka lansung terhadap individu atau kelompok yang sedang diteliti.

3. Studi Kepustakaan

Studi kepustakaan dilakukan dengan pengumpulan data dengan cara mempelajari buku, makalah, jurnal, website, dan skripsi untuk memperoleh informasi yang berhubungan dengan teori-teori dan konsep yang berkaitan dengan masalah dan variabel yang diteliti.

\section{Teknik Analisis Data}

Peneliti melakukan analisis data dengan menggunakan teknis analisis data sebagai berikut:

\section{Uji Validitas dan Reliabilitas}

Digunakan untuk mengetahui kelayakan butir-butir dalam suatu daftar pertanyaan. Validitas mengukur sejauh mana suatu alat ukur itu mengukur apa yang ingin anda ukur. Sehingga dapat dikatakan mampu memperoleh data yang tepat dari variabel yang diteliti. Validitas suatu butir pertanyaan dapat dilihat pada hasil output SPSS pada table Correlations jika butir pertanyaan valid terdapat $\left({ }^{*}\right)$ pada Pearson Correlation.

Mengenai uji reliabilitas, adalah suatu angka indeks yang menunjukan konsistensi suatu alat ukur dalam mengukur suatu gejala yang sama. Setiap alat ukur seharusnya memberikan hasil pengukuran yang konsisten (Husein Umar, 2005: 135). Suatu variabel dikatakan reliabel jika nilai cronbach alpha > 0,6 (Ghazali, 2001: 42).

Rumus cronbach alpha :

$$
\mathrm{r} \pi=\left[\frac{\mathrm{k}}{\mathrm{k}-1}\right]\left[\begin{array}{cc}
1-\frac{\sum \mathrm{ab}^{2}}{\mathrm{a}^{2}} & \\
&
\end{array}\right.
$$


Keterangan:

$\mathrm{r} \pi \quad$ : Realibilitas Instrumen

$\mathrm{k}$ : Banyaknya item pertanyaan atau pernyataan

$\sum \mathrm{ab}^{2}$ : Jumlah varian butir

$\mathrm{a} 1^{2} \quad$ : Varian total

2. Skala Likert

Pemahaman responden nasabah pada Lembaga Keuangan Mikro Syariah di Kota dan Kabupaten Bogor Provinsi Jawa Barat digunakan pendekatan deskriptif kuantitatif dengan menggunakan rata-rata (mean), yaitu pemberian skor yang didapatkan. Dari pemberian skor yang didapatkan, diperoleh interval antara satu kriteria dengan yang lainnya sebagai berikut:

Standar penilaian 1 sampai dengan 5

$$
\frac{5-1}{5}=0,80
$$

Dari hasil perhitungan 0,80 dijadikan patokan untuk memperoleh kriteria bagi minat adalah sebagai berikut:

a. Kriteria jawaban "sangat setuju" pada angka 4,20 - 5,00, dengan angka ratarata 4,6 .

b. Kriteria jawaban "setuju" pada angka 3,39 - 4,19, dengan angka rata-rata 3,79 .

c. Kriteria jawaban "kurang setuju" pada angka 2,58 - 3,38, dengan angka ratarata 2,98 .

d. untuk kriteria jawaban "tidak setuju" pada angka 1,77 - 2,57, dengan angka rata-rata 2,17.

e. Kriteria jawaban " sangat tidak setuju" pada angka 0,96 - 1,76, dengan angka rata-rata 1,36 .

Selanjutnya untuk memperoleh angka penafsiran atau interpretasi, maka digunakan rumus:

$$
\mathrm{M}=\frac{\sum(\mathrm{fx})}{\mathrm{N}}
$$

Keterangan:

$\mathrm{M}=$ perolehan angka kriteria penafsiran

$\mathrm{F}=$ frekuensi jawaban
$\mathrm{X}=$ pembobotan skor (skala nilai)

$\Sigma=$ penjumlahan

3. Uji Chi-Kuadrat (Chi-Square)

Merupakan salah satu penggunaan statistik untuk memutuskan apakah sebuah hipotesis ditolak atau diterima. Jika t hitung lebih besar dari $\mathrm{t}$ tabel, maka $\mathrm{H}_{\mathrm{o}}$ ditolak, sebaliknya jika $t$ hitung lebih kecil dari $t$ tabel maka $\mathrm{H}_{\mathrm{o}}$ diterima. Teknik ini dapat dilakukan apabila jumlah sampelnya lebih dari 30 agar hasil yang didapat tidak diragukan.

Rumus : $\mathrm{x}^{2}=\sum(o-e)^{2} / e$

$0=$ frekuensi hasil observasi.

e = frekuensi yang diharapkan.

Dengan degree of freedom atau $\mathrm{df}=\mathrm{N}-\mathrm{k} . \mathrm{N}$ adalah jumlah total pengamatan (data sampel), $\mathrm{k}$ adalah jumlah parameter yang diestimasi (variabel).

\section{HASIL DAN PEMBAHASAN}

\section{Gambaran Umum Koperasi Simpan Pinjam dan Pembiayaan Syariah di Kota dan Kabupaten Bogor}

Koperasi Simpan Pinjam dan Pembiayaan Syariah di Kota dan Kabupaten Bogor sebagian besar merupakan perubahan dari bentuk sebelumnya seperti Baitul Mal wa Tamwil, koperasi syariah maupun koperasi simpan pinjam. Namun demikian masih terdapat Lembaga Keuangan Mikro Syariah yang berbentuk Baitul Mal wa Tamwil. Berdasarkan penelusuran dari Tim Peneliti, maka diketahui yang masih aktif dan yang tidak aktif lagi. Diantara yang masih aktif tersebut, ada yang bersedia menjadi obyek penelitian, ada juga yang tidak bersedia menjadi obyek penelitian, dengan berbagai alasan.

Tim Peneliti telah mencoba melakukan penyebaran kuesioner sejak akhir bulan Juni hingga awal Agustus 2017. Penyebaran kuesioner tersebut meliputi Pengurus dan Nasabah di 24 (dua puluh empat) Koperasi Simpan Pinjam dan Pembiayaan Syariah (KSPPPS) dan Baitul Mal wa Tamwil (BMT) yang terdapat di Kota dan Kabupaten Bogor. Total 
keseluruhan kuesioner yang dapat terkumpul ialah sebanyak 458 kuesioner (458 responden). Selain hal tersebut, juga dilakukan wawancara terhadap beberapa Narasumber yang mengenal KSPPS dan BMT yang menjadi obyek penelitian tersebut. Kemungkinan besar, jumlah kuesioner dan Narasumber yang diwawancara akan bertambah, karena masih terdapat kuesioner dan data wawancara narasumber yang belum diolah dalam analisis sementara ini. Selain hal tersebut di atas, Tim Peneliti juga telah mencatat bahwa terdapat 10 KSPPS dan BMT yang tidak bersedia menjadi obyek penelitian, dan terdapat 29 KSPPS dan BMT yang sudah tidak aktif beroperasional lagi di Kota dan Kabupaten Bogor.

Rinciannya adalah sebagai berikut:

1. Nama KSPPS dan BMT yang Bersedia Menjadi Obyek Penelitian:

a. KSPPS Berkah Mandiri Sejahtera Cisarua. Belakang Pasar Cisarua. Jl. Citeko-Cisarua Puncak, Kecamatan Cisarua, Kabupaten Bogor, Jawa Barat 16750.

b. KSPPS Berkah Mandiri Sejahtera Cariu, Kecamatan Cariu, Kabupaten Bogor, Jawa Barat 16840.

c. KSPPS Berkah Bersama Caringin, Jl. Mayjen H. E.Sukma Nomor 363 , Kecamatan Caringin, Kabupaten Bogor, Jawa Barat 16730.

d. KSPPS Berkah Bersama Bogor Barat. Jl. Sindang Barang Nomor 6, Loji, Kecamatan Bogor Barat, Kota Bogor, Jawa Barat 16117.

e. KSPPS Berkah Bersama Cabang Cibinong, Jl. Raya Sukahati, Sukahati, Kecamatan Cibinong, Kabupaten Bogor, Jawa Barat 16913.

f. KSPPS Wihdatul Ummah. Jl. Mayor Jenderal Ishak Djuarsa Nomor 226 G, Gunungbatu, Kecamatan Bogor Barat, Kota Bogor, Jawa Barat 16118.

g. KSPPS Baitul Ikhtiar. Jl. Siaga, Komp. Pertanian Nomor 25 RT.02/RW.10, Kelurhan Loji,
Kecamatan Bogor Barat, Kota Bogor, Jawa Barat 16117.

h. BMT Mu'alimin, Jl. Aria Surialaga No. 26, Pasirkuda, Kecamatan Bogor Barat, Kota Bogor, Jawa Barat 16119.

i. $\quad$ BMT Aliya. Jl. Gardu Raya RT. 003 RW. 011, Bubulak, Kecamatan Bogor Barat, Kota Bogor, Jawa Barat 16115.

j. KSPPS Tadbiirul Ummah. Jl. Raya Dramaga No. 37, Kecamatan Dramaga, Kabupaten Bogor, Jawa Barat 16680.

k. KSPPS Annajah Solution, Jl. Achmad Adnawijaya, Nomor 26, Bantarjati, Kecamatan Bogor Utara, Kota Bogor, Jawa Barat.

l. KSPPS Binaul Ummah. Jl. R.E. Sumartadireja No. 13, Pamoyanan, Kecamatan Bogor Selatan, Kota Bogor, Jawa Barat 16136.

m. KSPPS Fajar. Komplek Ruko Permata Cibubur, Jl. CileungsiJonggol Blok H6 No. 46, Cileungsi Kidul, Kecamatan Cileungsi, Kabupaten Bogor, Jawa Barat 16820.

n. BMT Miftahul Huda. Jl. Letkol Atang Sanjaya no. 111A Rt01/0,1 Desa Bantar Jaya, Kecamatan Rancabungur, Kabupaten Bogor, Jawa Barat 16310.

o. KSPPS Sidogiri UGT Leuwiliang. Jl. Kerekel Kampung Sawah, Kecamatan Leuwiliang, Kabupaten Bogor, Jawa Barat 16640.

p. KSPPS Sidogiri UGT Cibinong, Jl. Tapos Raya Nomor 18, Ciriung, Kecamatan Cibinong, Bogor, Jawa Barat 16918.

q. BMT An Nisa Muhammadiyah Cileungsi. Perumahan PTSC. Jl. Anggrek Nomor 25, Kecamatan Cileungsi, Bogor 16820.

r. KSPPS Darussalam Madani. Ruko Fresh Market, Jl. Boulevard Kota Wisata Blok FMR. 6 Nomor 18, Desa Ciangsana, Kecamatan 
Gunung Putri, Kabupaten Bogor, Jawa Barat 16968.

s. BMT Baiturrahman. Masjid Baiturrahman. Jl. Raya Perumahan Bambu Kuning, Blok B 2, RW 14 RT 11, Desa Bojong Gede, Kecamatan Bojong Gede, Bogor, Jawa Barat 16320.

t. BMT Pondok Pesantren Darul Muttaqien Jl. Raya Jakarta Bogor Km. 41. Jabon Mekar, Kecamatan Parung, Kabupaten Bogor 16330.

u. BMT Al Asiyah Ling. 04 Kranji Barat Rt. 01/11, Desa Ciriung, Kecamatan Cibinong, Kabupaten Bogor, Jawa Barat.

v. KSPPS Mitra Usaha Syariah. Jl. KH. Abdul Hamid, Km. 15 Desa Ciasmara, Kecamatan Pamijahan, Kabupaten Bogor, Jawa Barat 16810.

w. KSPPS Khairu Ummah Leuwiliang (dan Cabang Leuwisadeng). Jl. Raya Leuwiliang No. 102, Leuwimekar, Kecamatan Leuwiliang, Kabupaten Bogor, Jawa Barat 16640.

x. KSPPS Sahid Husnul Khotimah [Institut Agama Islam Sahid (INAIS) Bogor] Jl. K.H. Abdul Hamid Km. 6, Gunung Menyan, Kecamatan Pamijahan, Kabupaten Bogor, Jawa Barat 16810.

2. Nama KSPPS dan BMT yang Tidak Bersedia Menjadi Obyek Penelitian:

a. BMT At Ta'awun. Jl. Perum Indraprasta, Tegal Gundil, Kecamatan Bogor Utara, Kota Bogor, Jawa Barat 16154.

b. KSPPS Tunas Artha Mandiri Syariah. Jl. Gatotkaca Raya Nomor 15, Bantarjati, Kecamatan Bogor Utara, Kota Bogor, Jawa Barat 16151.

c. BMT Aqobah Parung. Masjid Riyadus Solihin, Jl. Raya Parung, Pemagarsari, Kecamatan Parung, Kabupaten Bogor, Jawa Barat 16330.

d. KSPPS UGT Sidogiri. Jl. H. Mawi, Nomor 3, Waru, Kecamatan
Parung, Kabupaten Bogor, Jawa Barat 16330.

e. KSPPS El Umma. Jl. Warung Borong Rt 02/05 Nomor 27, Kecamatan Ciampea, Kabupaten Bogor, Jawa Barat 16620.

f. KSPPS Khidmatul Ummah. Jl. Raya Cemplang Nomor 31, Km 18 Cemplang, Dukuh Cibungbulang, Kecamatan Cibungbulang, Kabupaten Bogor, Jawa Barat 16630.

g. BMT Pondok Pesantren AlKarimah. Jl. Raya Pemda, RT.04/RW.02, Pasir Jambu, Kecamatan Sukaraja, Kabupaten Bogor, Jawa Barat 16710.

h. BMT Sejahtera Bangsaku. Jl. H. Juanda, Desa Citaringgul, Kecamatan Babakan Madang, Kabupaten Bogor, Jawa Barat 16810. (Hanya Perwakilan dari Kantor di Tasikmalaya dengan Nasabah berdomisili di Kota dan Kabupaten Tasikmalaya Jawa Barat).

i. KSPPS Amanah Insani. Jl. Raya Kapten Yusup, Nomor 7 C, Cikaret, Komplek Ruko Cikaret, Dayeuh, Kecamatan Cileungsi, Kabupaten Bogor, Jawa Barat 16820.

j. KSPPS Karya Usaha Mandiri Cabang Cisarua Megamendung, Jl. Cikopo Selatan, Desa Sukamanaha, Kecamatan Megamendung, Kabupaten Bogor, Jawa Barat 16770.

3. Nama KSPPS dan BMT yang Sudah Tidak Beroperasional atau Tidak Aktif.

a. BMT Amal Atina. Jl. Cempedak Raya, Nomor 9, Bantar Kemang, Baranangsiang, Kecamatan Bogor Timur, Kota Bogor, Jawa Barat 16143.

b. BMT Lebah. Jl. KH. Soleh Iskandar, Curug, Cibadak, Kecamatan Tanah Sereal, Kota Bogor, Jawa Barat 16166.

c. BMT Mitra Muamalah Syariah. Jl. KH. Abdullah Bin Nuh, Ruko 
Yasmin Sektor VI Nomor 196 Lt. 2, Curug Mekar, Kecamatan Bogor Barat, Kota Bogor, Jawa Barat 16113.

d. BMT Tabung Umat. Perumahan Bukit Mekar Wangi. Blok C 17 Nomor 36. Kecamatan Tanah Sereal, Kota Bogor, Jawa Barat 16168.

e. BMT Rahmatan Lil 'Alamin. Jl. HM. Sukma RT.01 RW.12 Nomor45, Harjasari, Kecamatan Bogor Selatan, Kota Bogor, Jawa Barat 16138.

f. BMT Sahabat. Jl. Babakan Sari VI Nomor7 RT.006/005, Babakan, Kecamatan Bogor Tengah, Kota Bogor, Jawa Barat 16128.

g. BMT Utama Syariah. Jl. Kesehatan Nomor 4, Tanah Sereal, Kecamatan Tanah Sereal, Kota Bogor, Jawa Barat 16161.

h. BMT Al-Ikhlas. Jl. Baranangsiang Indah Rt.04/XI, Katulampa, Kecamatan Bogor Timur, Kota Bogor, Jawa Barat 16144. (Hanya Menerima dan Menyalurkan Zakat, Waqaf, Infaq dan Shodaqoh).

i. BMT Fastabiqul Khoirot. Jl. Tentara Pelajar Nomor 3 A. Menteng, Kecamatan Bogor Barat, Kota Bogor, Jawa Barat 16111.

j. BMT Wahana Insan Muamalah (WASILAH), Jl. Perintis Kemerdekaan Nomor 18, Rt. 004/Rw. 03, Kebon Kelapa, Kecamatan Bogor Tengah, Kota Bogor, Jawa Barat 16125.

k. BMT An Najah. Masjid Agung Bogor, Jl. Dewi Sartika No. 10, RT.06 / RW.04, Pasar Kebon Kembang, Cibogor, Kecamatan Bogor Tengah, Kota Bogor, Jawa Barat 16124.

l. KSPPS Ibadurrahman. Jl. Tol Jagorawi Nomor 3, Kecamatan Ciawi, Kabupaten Bogor, Jawa Barat 16720.

m. BMT Koperasi Zamzam. Jl. Mayor Oking Nomor 20-B, Cijayanti,
Kecamatan Babakan Madang, Kabupaten Bogor, Jawa Barat 16810.

n. BMT Al Ikhlas. Jl. Raya Perumahan Bukit Asri Masjid Al Ikhlas Bogor, Kecamatan Ciomas, Kabupaten Bogor, Jawa Barat 16617. (Hanya Menerima dan Menyalurkan Zakat, Waqaf, Infaq dan Shodaqoh).

o. BMT Aqobah, Jl. Bersih, Nomor 1 Rt. 003 Rw. 001, Tengah, Cibinong Tengah, Kecamatan Cibinong, Kabupaten Bogor, Jawa Barat 16914.

p. BMT Darussalam. Jl. Veteran 3, RT 01 RW 04, Jambuluwuk, Cukang Galeuh, Cibedug, Kecamatan Ciawi, Kabupaten Bogor, Jawa Barat 16720.

q. KSPPS Bina Insani Mandiri. Jl. Pahlawan Nomor 258, Sanja, Kecamatan Citeureup, Kabupaten Bogor, Jawa Barat 16810.

r. BMT Bumi Putera. Komplek Telaga Kahuripan Gugus Beranda Ganesha Blok C.6 Nomor 7 Desa Tegal, Kecamatan Kemang, Kabupaten Bogor, Jawa Barat 16310.

s. BMT Al-Falah. Masjid Al Falah. Depan Kantor Urusan Agama Cariu. Jl. Brigjen Dharsono, Kecamatan Cariu, Kabupaten Bogor, Jawa Barat 16840.

Dari 458 responden, 6 responden sebagai Pegawai Negeri Sipil atau Tentara Nasional Indonesia, 90 responden sebagai Pegawai Swasta, 212 responden sebagai Wiraswasta dan Wirausaha, 81 responden sebagai Ibu Rumah Tangga, 49 responden sebagai Pelajar atau Mahasiswa, 20 responden sebagai lainnya di luar kualifikasi tersebut. 


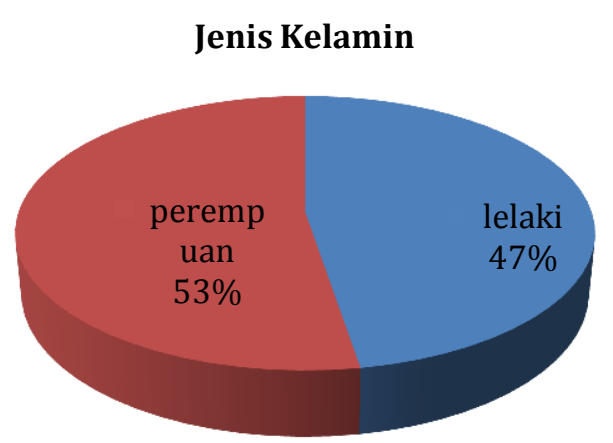

Gambar 1. Sebaran Jenis Kelamin Responden

Dari 458 responden, 92 lulusan sekolah dasar, 88 responden lulusan sekolah menengah pertama, 180 responden lulusan sekolah menengah atas, 30 responden sebagai lulusan program diploma, 66 responden lulusan sarjana, pasca sarjana dan doktor dan 2 responden sebagai lainnya di luar kualifikasi tersebut.

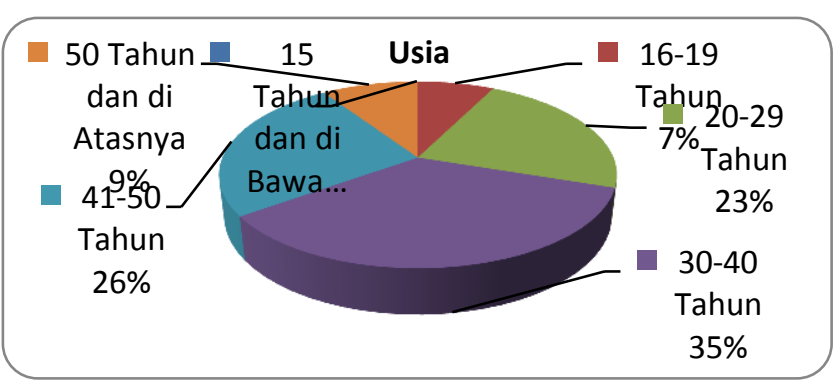

Gambar 2. Sebaran Tingkat Pendidikan Responden

\section{UJI CHI-KUADRAT KUESIONER.}

(CHI-SQUARE)

Keterkaitan Variabel EkonomiKelembagaan, Variabel PelayananKelembagaan, Variabel Substansi Kontrak Bisnis Syariah, dan Variabel Sosial Budaya Masyarakat, secara Bersama-sama dengan Pemahaman Nasabah terhadap Kontrak Bisnis Syariah pada Lembaga Keuangan Mikro Syariah.

Berdasarkan hasil penelitian diperoleh perhitungan chi-square hitung sebesar 29312. Dengan degree of freedom atau $\mathrm{df}=\mathrm{N}-\mathrm{k}$, yang mana $\mathrm{N}$ adalah jumlah total pengamatan (data sampel), $\mathrm{k}$ adalah jumlah parameter yang diestimasi (variabel), maka berdasarkan $\mathrm{df}=458-4=$
454, dengan taraf signifikansi sebesar 5\%, maka diperoleh nilai chi-square tabel sebesar 504,676.

Dengan demikian, dapat diketahui bahwa nilai chi-square hitung lebih besar dari nilai chi-square tabel (29312 > 504,676). Dengan demikian Ho ditolak dan Hi diterima, artinya bahwa variabel ekonomi-kelembagaan, variabel pelayanankelembagaan, variabel substansi kontrak bisnis syariah, dan variabel sosial budaya masyarakat secara bersama-sama mempunyai keterkaitan dengan pemahaman nasabah terhadap kontrak bisnis syariah pada Lembaga Keuangan Mikro Syariah. Hal tersebut berbanding lurus dengan perhitungan angka penafsiran dalam skala likert di atas, yang berada pada rata-rata kesetujuan yang kuat.

\section{MODEL PENYULUHAN TERHADAP NASABAH MENGENAI KONTRAK BISNIS SYARIAH PADA TRANSAKSI DI LEMBAGA KEUANGAN MIKRO SYARIAH}

\section{Pemahaman Nasabah mengenai Lembaga Keuangan Mikro Syariah dan Kontrak Bisnis Syariah}

Analisis kuantitatif yang ditunjukkan sebelumnya memperlihatkan hal yang menggembirakan mengenai respon masyarakat yang menjadi nasabah pada Lembaga Keuangan Mikro Syariah. Nilai kesetujuan begitu kuat dalam setiap variabel yang diuji, menandakan bahwa terdapat potensi loyalitas dari nasabah untuk tetap menjadi nasabah dan bahkan mengajak yang lainnya agar menjadi nasabah seperti dirinya.

Namun demikian, berdasarkan penelitian yang dilakukan dengan wawancara, peneliti mendapatkan bahwa pemahaman nasabah mengenai kontrak bisnis syariah, masih sederhana atau terbatas.

Pemahaman Nasabah mengenai Lembaga Keuangan Mikro Syariah, Termasuk di Dalamnya mengenai Kontrak Bisnis Syariah (Bagian 1), maka terlihat bahwa pemahaman sebagian besar 
responden nasabah masih dalam "Tahap Menerjemahkan" sejauh yang dilihat saat bertransaksi dengan Lembaga Keuangan Mikro Syariah. Jawaban-jawaban tersebut masing-masing berdasarkan pemahaman responden nasabah yang berbeda satu sama lain. Masing-masing responden hanya mempunyai satu jawaban.

Dengan demikian, sesuai jumlah jawaban yang ada pada tabel tersebut di atas, maka terdapat jawaban dari 33 responden nasabah. 12 responden nasabah berada pada kolom "Tahap Belum Paham", sedangkan 21 responden nasabah berada pada kolom "Tahap Menerjemahkan".

Pemahaman Nasabah mengenai Lembaga Keuangan Mikro Syariah, Termasuk di Dalamnya mengenai Kontrak Bisnis Syariah (Bagian 2), maka terlihat bahwa pemahaman sebagian besar responden nasabah masih dalam "Tahap Menginterpretasikan" sejauh yang dilihat saat bertransaksi dengan Lembaga Keuangan Mikro Syariah. Jawaban-jawaban tersebut masing-masing berdasarkan pemahaman responden nasabah yang berbeda satu sama lain. Masing-masing responden hanya mempunyai satu jawaban.

Dengan demikian, sesuai jumlah jawaban yang ada pada tabel tersebut di atas, maka terdapat jawaban dari 9 responden nasabah. 7 responden nasabah berada pada kolom "Tahap Menginterpretasikan", sedangkan 2 responden nasabah berada pada kolom "Tahap Mengekstrapolasikan".

Secara kuantitatif, tentu jumlah 42 responden nasabah tersebut tidak dapat merepresentasikan mengenai pemahaman responden nasabah secara keseluruhan yang berjumlah 458 responden nasabah. Namun demikian, secara kualitatif, hal ini dapat dirasakan bahwa mayoritas responden nasabah masih mempunyai pemahaman yang sederhana atau terbatas.

Berdasarkan teori pemahaman yang tersebut di dalam bab "Tinjauan Pustaka", maka tahap pemahaman dalam tabel di atas sedikit berbeda, yaitu dengan ditambahkannya "Tahap Belum Paham". Hal ini ditambahkan oleh peneliti karena jawaban yang diberikan oleh responden nasabah masih ada yang belum termasuk dalam kriteria tingkat pemahaman menurut Suke Silversius (Suke Silversius, 1991: 43-44).

Bahkan mungkin jika "benar-benar" secara ketat bahwa jawaban dari responden nasabah disesuaikan dengan kriteria tersebut, mungkin sangat sedikit responden nasabah yang sesuai dengan kriteria tersebut, termasuk untuk kriteria "Tahap Menerjemahkan". Hal ini karena sangat sedikit responden nasabah yang mampu memberikan jawaban dengan contoh simbolik dalam menerangkan mengenai Lembaga Keuangan Mikro Syariah, termasuk di dalamnya mengenai kontrak bisnis syariah.

\section{Pemahaman Nasabah mengenai Peran Lembaga Keuangan Mikro Syariah}

Meskipun analisis kuantitatif yang ditunjukkan sebelumnya memperlihatkan hal yang menggembirakan mengenai respon masyarakat yang menjadi nasabah pada Lembaga Keuangan Mikro Syariah, terutama dalam hal yang dihubungkan dengan peran Lembaga Keuangan Mikro Syariah, penelusuran secara kualitatif perlu dilakukan untuk saling melengkapi antara kuantitatif dengan kualitatif.

Dalam hal ini, misalnya "Variabel Ekonomi Kelembagaan" dan "Variabel Pelayanan Kelembagaan" begitu kuat nilai kesetujuannya dalam skala likert maupun uji chi square. Hal ini sangat positif jika dihubungkan bahwa hal persepsi responden nasabah pun demikian positif pula secara kualitatif. Jika persepsi positif begitu kuatnya dibandingkan persepsi negatif, maka hal ini menandakan juga bahwa terdapat potensi loyalitas dari nasabah untuk tetap menjadi nasabah dan bahkan mengajak yang lainnya agar menjadi nasabah seperti dirinya. Selain itu, mudah pula untuk diberikan penyuluhan oleh Lembaga Keuangan Mikro Syariah. Persepsi adalah kemampuan otak dalam 
menerjemahkan stimulus atau proses untuk menerjemahkan stimulus yang masuk ke dalam alat indera manusia. Persepsi manusia terdapat perbedaan sudut pandang dalam penginderaan. Ada yang mempersepsikan sesuatu itu baik atau persepsi yang positif maupun persepsi negatif yang akan mempengaruhi tindakan manusia yang tampak atau nyata (Sugihartono, dkk 2007: 8). Tidak menutup kemungkinan bahwa persepsi positif responden nasabah akan berpengaruh pada persepsi positif lingkungannya terhadap Lembaga Keuangan Mikro Syariah.

Berdasarkan penelitian yang dilakukan dengan wawancara, peneliti mendapatkan bahwa pemahaman nasabah mengenai peran Lembaga Keuangan Mikro Syariah, sebagian besar responden nasabah masih dalam "Persepsi Positif" dibandingkan "Persepsi Negatif". Sama seperti halnya dalam bagian di atas, bahwa jawaban-jawaban tersebut masing-masing berdasarkan pemahaman responden nasabah yang berbeda satu sama lain. Masing-masing responden hanya mempunyai satu jawaban.

Dengan demikian, sesuai jumlah jawaban yang ada, maka terdapat jawaban dari 42 responden nasabah. 38 responden nasabah berada pada kolom "Persepsi Positif", sedangkan 4 responden nasabah berada pada kolom "Persepsi Negatif".

Secara kuantitatif, tentu jumlah 42 responden nasabah tersebut tidak dapat merepresentasikan mengenai pemahaman responden nasabah secara keseluruhan yang berjumlah 458 responden nasabah. Namun demikian, secara kualitatif, hal ini dapat dirasakan bahwa mayoritas responden nasabah masih mempunyai persepsi positif mengenai Peran Lembaga Keuangan Mikro Syariah.

\section{Model Penyuluhan oleh Lembaga Keuangan Mikro Syariah}

Dengan mengetahui pemahaman responden atau nasabah yang masih sederhana atau terbatas, maka diperlukan suatu model penyuluhan oleh Lembaga
Keuangan Mikro Syariah kepada nasabah. Penyuluhan ini penting dilakukan agar Nasabah mempunyai pemahaman yang semakin meningkat dalam memahami Lembaga Keuangan Mikro Syariah, termasuk di dalamnya ialah kontrak bisnis syariah.

Penyuluhan ini mempunyai "basis" dukungan dengan adanya persepsi positif dari nasabah mengenai peran Lembaga Keuangan Mikro Syariah. Persepsi positif tersebut menjadi potensi dasar loyalitas nasabah kepada Lembaga Keuangan Mikro Syariah. Potensi loyalitas ini harus terus dikonsolidasikan oleh Lembaga Keuangan Mikro Syariah agar potensi loyalitas tersebut terus menguat.

Berkaitan dengan hal tersebut di atas, maka penting direncanakan suatu model penyuluhan yang dilakukan oleh Lembaga Keuangan Mikro Syariah. Salah satu hal yang menarik ialah bahwa penting untuk melibatkan partisipasi masyarakat yang lebih banyak, dengan model penyuluhan yang berbasis peran aktif masyarakat. Hal ini sangat relevan jika mengingat bahwa Lembaga Keuangan Mikro Syariah mempunyai substansi sebagai lembaga yang berasal dari masyarakat itu sendiri. Ini terdapat dalam perundang-undangan bahwa Lembaga Keuangan Mikro adalah lembaga keuangan yang khusus didirikan untuk memberikan jasa pengembangan usaha dan pemberdayaan masyarakat, baik melalui pinjaman atau pembiayaan dalam usaha skala mikro kepada anggota dan masyarakat, pengelolaan simpanan, maupun pemberian jasa konsultasi pengembangan usaha yang tidak sematamata mencari keuntungan (UndangUndang Nomor 1 Tahun 2013 tentang Lembaga Keuangan Mikro: Pasal 1 angka 1). Dalam hal Lembaga Keuangan Mikro Syariah dengan kegiatan usaha berdasarkan prinsip syariah, maka kegiatan usaha tersebut wajib dilaksanakan sesuai dengan fatwa syariah yang dikeluarkan oleh Dewan Syariah Nasional, Majelis Ulama Indonesia. (Undang-Undang 
Nomor 1 Tahun 2013 tentang Lembaga Keuangan Mikro: Pasal 12 ayat 1 dan 2). Dengan demikian, maka:

1. Lembaga Keuangan Mikro Syariah menerapkan model penyuluhan yang berbasis partisipasi aktif dari masyarakat.

2. Lembaga Keuangan Mikro Syariah mengutamakan proses dalam melakukan kegiatan, terutama proses pemahaman kontrak bisnis syariah.

3. Posisi masyarakat sebagai subyek dalam penyuluhan. Dengan demikian, masyarakat tidak hanya dalam posisi sebagai pendengar, tetapi sekaligus sebagai Narasumber, terutama dalam hal permasalahan yang terjadi di lapangan berkaitan dengan Lembaga Keuangan Mikro Syariah.

4. Meskipun hubungan kerja antara masyarakat (yang sudah menjadi nasabah) dengan Lembaga Keuangan Mikro Syariah bersifat formal dan berdasarkan kontrak bisnis syariah, namun demikian pada dasarnya ialah kemitraan sesuai perundang-undangan. Hubungan ini juga dilandasi semangat budaya kekeluargaan, kegotongroyongan, dan kebhinekaan. Prinsip kemitraan dengan semangat budaya tersebut juga menjadi landasan dalam hubungan antara masyarakat (yang berpotensi menjadi Nasabah) dengan Lembaga Keuangan Mikro Syariah.

5. Dengan hubungan kerja tersebut, diharapkan program tetap berkelanjutan, dilaksanakan secara terogranisis dan tahap demi tahap sampai dengan kegiatan yang sesuai dengan kesepakatan bersama.

6. Dalam penyuluhan, ditekankan bahwa pemecahan masalah yang akan terjadi terlebih dahulu dilakukan secara bersama-sama dengan masyarakat dan dalam hal tertentu dapat melibatkan pemuka agama dan tokoh masyarakat. Dalam hal yang berkaitan dengan pelanggaran hukum perdata, sebelum dilakukan dengan lembaga pemerintahan yang ada, maka sedapat mungkin dilselesaikan melalui musyawarah.

Dengan demikian, masyarakat menjadi terlayani dengan baik, dan diharapkan potensi kreativitas masyarakat akan tumbuh dan berkembang.

\section{KESIMPULAN DAN IMPLIKASI}

Kesimpulan

Setelah peneliti melakukan penelitian ini, maka kesimpulan yang dapat dihasilkan adalah sebagai berikut:

1. Berkaitan dengan pemahaman nasabah terhadap kontrak bisnis syariah pada Lembaga Keuangan Mikro Syariah di Kota dan Kabupaten Bogor, maka di luar variabel demografi, terdapat variabel-variabel yang berkaitan dengan hal tersebut, yang dapat diterangkan sebagai berikut:

a. Bahwa variabel ekonomikelembagaan, variabel pelayanankelembagaan, variabel substansi kontrak bisnis syariah, dan variabel sosial budaya masyarakat secara masingmasing mempunyai keterkaitan yang kuat dengan pemahaman nasabah terhadap kontrak bisnis syariah pada Lembaga Keuangan Mikro Syariah.

b. Bahwa variabel ekonomikelembagaan, variabel pelayanankelembagaan, variabel substansi kontrak bisnis syariah, dan variabel sosial budaya masyarakat secara bersama-sama mempunyai keterkaitan yang kuat dengan pemahaman nasabah terhadap kontrak bisnis syariah pada Lembaga Keuangan Mikro Syariah.

2. Pemahaman nasabah mengenai kontrak bisnis syariah, masih sederhana atau terbatas. Secara kualitatif, jika dihubungan dengan teori pemahaman, maka nasabah 
Lembaga Keuangan Mikro Syariah di Kota dan Kabupaten Bogor, masih dalam tahap pemahaman "Menerjemahkan" dan "Belum Paham" dibandingkan tahap pemahaman "Menginterpretasi", dan terlebih tahap pemahaman "Mengekstrapolasi.

Persepsi nasabah bernilai positif dalam memandang peran Lembaga Keuangan Mikro Syariah di Kota dan Kabupaten Bogor. Secara kualitatif, hal ini dapat dirasakan bahwa mayoritas responden nasabah masih mempunyai persepsi positif mengenai Peran Lembaga Keuangan Mikro Syariah. Hal ini merupakan pertanda baik bahwa Lembaga Keuangan Mikro Syariah dapat melakukan penyuluhan mengenai kontrak bisnis syariah kepada para nasbah maupun masyarakat yang berpotensi menjadi nasabah.

Saran

Setelah peneliti membuat kesimpulan tersebut di atas, maka saran yang dapat diusulkan adalah sebagai berikut:

1. Lembaga Keuangan Mikro Syariah dimaksudkan untuk memberikan fasilitas dan kemudahan bagi masyarakat yang membutuhkan biaya untuk keperluan konsumtif ataupun produktif dengan tujuan untuk pemulihan dan pemberdayaan ekonomi melalui bantuan modal kerja, pelatihan dan pendampingan usaha. Dengan hal tersebut, maka prinsip kemitraan yang menjadi ciri khas utama dari Lembaga Keuangan Mikro Syariah dengan masyarakat yang menjadi nasabah harus terus ditingkatkan dengan menekankan pada pemahaman mengenai kontrak bisnis syariah, termasuk dalam hal ini ialah pada masyarakat yang berpotensi menjadi nasabah, misalnya kelompok usaha mikro kecil dan menengah di masyarakat.

2. Lembaga Keuangan Mikro Syariah di Kota dan Kabupaten Bogor, dapat memanfaatkan persepsi positif yang ada pada masyararakat $y$ ang menjadi nasabah dan responden terhadap Lembaga Keuangan Mikro Syariah. Memanfaatkannya, dengan melakukan pendekatan yang mengajak peran aktif masyarakat dalam suatu gagasan yang berbasis model penyuluhan yang bersifat bottom up. Masyarakat tidak lagi hanya sebagai obyek yang selama ini dipersepsikan oleh sebagian masyarakat, terutama dalam kegiatan penyuluhan, tetapi masyarakat diperlakukan sebagai subyek. Masyarakat dapat menggagas kreativitas yang diperlukan dalam menghadapi permasalahan di dalam praktik yang berkaitan dengan Lembaga Keuangan Mikro Syariah.

Meskipun kelak baik pada saat maupun setelah penyuluhan, hubungan kerja antara masyarakat (yang sudah menjadi nasabah) dengan Lembaga Keuangan Mikro Syariah bersifat formal dan berdasarkan kontrak bisnis syariah, namun demikian pada dasarnya ialah kemitraan sesuai perundang-undangan. Hubungan ini juga dilandasi semangat budaya kekeluargaan, kegotongroyongan, dan kebhinekaan. Prinsip kemitraan dengan semangat budaya tersebut juga menjadi landasan dalam hubungan antara masyarakat (yang berpotensi menjadi Nasabah) dengan Lembaga Keuangan Mikro Syariah. Semangat budaya tersebut dapat memudahkan hubungan antara Lembaga Keuangan Mikro Syariah dengan masyarakat menjadi lebih luwes dan tidak kaku.

\section{DAFTAR PUSTAKA}

Abdullah M. 2015. Metodologi Penelitian Kuantitatif.

Penyunt.) Aswaja Pressindo.

Alhifni A., \& Huda, N. 2015. Kinerja LKMS dalam Mendukung Kegiatan Ekonomi Rakyat Berbasis Pesantren (Studi Pondok Pesantren Darut Tauhid dan 
BMT darut Tauhid). Jurnal Aplikasi Manajemen , 598.

BPS Kota Bogor. 2015. Kota Bogor Dalam Angka. Bogor: BPS Kota Bogor.

Ginting I.,Sudrajat I. 2013. Analisis Strategi Pengembangan BMT (Baitul Maal Wa Tamwil) di Kota Medan. Jurnal Ekonomi dan Keuangan, Volume 2 Nomor 11.

Hafidloh. 2015. Pengaruh Gaya Kepemimpinan Budaya Organisasi Terhadap Kinerja LKMS.

Hapsari., Hidayatullah M., \& Indri M. 2015. Peran Pembiayaan Produktif BMT Mandiri Mulia Terhadap Peningkatan Kesejahteraan Anggota Perspektif Maqasid Syariah. JESTT Volume 2 Nomor $10,799$.

Kara., \& Muslim., 2013. Kontribusi Pembiayaan Perbankan Syariah terhadap Pengembangan Usaha Mikro, Kecil dan Menengah. Ahkam, XIII nomor 2.

Lukitawati Anggraeni L., Puspitasari H., Ayyubiah S., \& Wiliasari R 2013. Akses UKMK Terhadap Pembiayaan Mikro Syariah dan Dampaknya Terhadap Perkembangan Usaha : Kasus BMT Tadbiirul Ummah Kabupaten Bogor. Jurnal AlMuzara'ah Volume 1 Nomor 1 , 56-67.

Mi'raj, Abdurrahman D. 2015. Linkage Program Bank Syariaha dengan Bmt: Tinjauan Kritis bagi Pengembangan Sistem Keuangan Islam Yang Kaffah. JESTT nomor 10 , volume 2 .

Sukmayani R., Thomas K., Umang., Sedono., Kristianto S., Raharjo D., 2004. Ilmu Pengetahuan Sosial 3. jakarta: PT Gramedia Kompas Gramedia Building. Tsalastia A, Syarif R. \& Suryahadi. 2010. Kajian Program Misykat (Microfinance Syariah Berbasis Masyarakat) sebagai Alternatif Pilihan Porgram Pemberdayaan Usaha Mikro (Studi Kasus pada Dompet Peduli Umat Daarut Tauhid
Mulyaningsih Y., Nuryantono N., Oktaviani R., Firdausy C., 2015. Analisis Jangkauan (Outreach) LKMS bagi Rumahtangga Miskin Sektor Pertanian di Pedesaan Bogor, Jawa Barat. jurnal Ilmu Pertanian indonesia , 183.

Muhammad. 2000. Lembaga-Lembaga Keuangan Umat Kontemporer. UII Press.

Nofiawati. 2015. Baitul Maal Wa Tamwil : Peluang dan Tantangan pengembangan LKMS di Kota Padangsidimpuan. Volume 1 Nomor 1.

Prihantono. 2014. Peran Bank dan Pegadaian Syariah dalam Pemenuhan Kebutuhan Ekonomi Rumah Tangga. Jurnal Khatulistiwa-Journal of Islamic SStudies Volume 4 Nomor 1 , 63-72.

Ridwan, M. 2004. Manajemen Baitul Maal Wa Tamwil (BMT). Yogyakarta: UII Press.

Rima., Dasuki., 2011. Optimalisasi Menciptakan Market Value Lembaga Keuangan Mikro Syariah (LKMS) untuk Pemberdayaan Usaha Kecil Menengah (UKM) melalui Pendekatan Resource Based View. Jurnal Coopetition Volume II NO. $1,3$.

Sudarsono. 2012. Bank dan Lembaga Keuangan Syariah Deskripsi dan Ilusrasi edisi ketiga. Ekonosia , 107.

Sugiarto SD. (2006). Metode Statistika. Jakarta: PT Gramedia Pustaka Utama.

Sugiyono. 2016. Metode Penelitian Kombinasi (mixed methods). Bandung: Alfabeta.

Bogor). Manajemen IKM volume 5 nomor $1,12$.

Wijoyo M. 1999. Kinerja Lembaga Keuangan Mikro dan Prilaku Masyarakat Pedesaan. Buletin Ekonomi Moneter dan Perbankan Volume 1 Nomor 4.

Yusuf SD., 2014. Peran Strategis Baitul Maal Wa Tamwil (BMT) Dalam Peningkatan Ekonomi Rakyat. Jurnal Al-Mizan, Volume 10 nomor 1. 